\title{
Composición química, contenido de proteína, aminoácidos y morfología de gónadas de erizo de mar (Strongylocentrotus franciscanus)
}

\author{
Sea urchin (Strongylocentrotus franciscanus) gonads chemical composition, protein and \\ amino acid contents and morphology
}

\begin{abstract}
Dulce Alondra Cuevas-Acuña ${ }^{2}$, Martina Hilda Gracia Valenzuela' ${ }^{1}$ Hisila C. Santacruz-Ortega ${ }^{3}$, Ramón Gertrudis Valdez Melchor', Joe Luis Arias-Moscoso'

Instituto Tecnológico del Valle del Yaqui, Block 611, Bácum, San Ignacio Río Muerto, Ciudad Obregón, Sonora, México.

2 Departamento de Ciencias de la Salud. Universidad de Sonora. Blvd. Bordo Nuevo s/n, Antiguo Ejido Providencia. Cajeme, Sonora, México. C.P. 85010.

Departamento de Investigación en Polímeros y Materiales, Universidad de Sonora, Hermosillo, México.
\end{abstract}

\section{RESUMEN}

Las características físicas y químicas de las gónadas de erizo S. franciscanus fueron estudiadas usando métodos destructivos y no destructivos. Los organismos fueron recolectados en San Carlos, Nuevo Guaymas y procesados para ser evaluados. Se determinó la composición proximal de las gónadas obteniéndose el contenido de proteínas, lípidos, cenizas y humedad con valores de $13.63 \% \pm 0.57 ; 5.04 \% \pm 0.4$; $3.73 \% \pm 0.05 ; 75.40 \% \pm 0.51$ respectivamente. Para el estudio del perfil proteico, las gónadas se analizaron mediante electroforesis en gel de poliacrilamida disociante donde se obtuvieron numerosas fracciones relacionadas a proteínas sarcoplasmáticas y miofibrilares. Por otra parte, la composición de aminoácidos mostró la presencia de aminoácidos esenciales, siendo predominantes la leucina y la treonina; mientras que los aminoácidos no esenciales predominantes fueron ácido aspártico, acido glutámico y glicina. Además, la presente investigación muestra por primera vez las características morfológicas, usando microscopía electrónica de barrido, de las gónadas de erizo detectando la presencia de estructuras globulares relacionadas con la presencia de actina. Los resultados del estudio sobre la caracterización parcial mejorará la comprensión de las propiedades fisicoquímicas de las gónadas de erizo $S$. franciscanus, que ayudarán a determinar su aprovechamiento como fuentes novedosas de alimentos nutricionales o funcionales.

Palabras clave: Strongylocentrotus franciscanus, gónadas, morfología, proteína, erizo de mar.

\section{ABSTRACT}

Some physical and chemical characteristics of the S. franciscanus sea urchin gonads were studied using destructive and non-destructive methods. The organisms were collected in San Carlos, Nuevo Guaymas and processed to be evaluated. The proximal composition of the gonads was determined obtaining the content of proteins, lipids, ashes and humidity with values of $13.63 \% \pm 0.57 ; 5.04 \% \pm 0.4 ; 3.73 \%$ $\pm 0.05 ; 75.40 \% \pm 0.51$ respectively. For the protein profile study, gonads were analyzed by dissociating polyacrylamide gel electrophoresis where numerous fractions related to

\section{Volumen XXI, Número 3}

sarcoplasmic and myofibrillar proteins were obtained. On the other hand, the amino acids composition revealed the presence of essential amino acids, being the most predominant leucine and threonine; while predominant non-essential amino acids were aspartic acid, glutamic acid and glycine. In addition, this research shows for the first time the morphological characteristics, by scanning electron microscopy, of the $S$. franciscanus gonads and the presence of globular structures related to the presence of actin. The results on the partial characterization improve the understanding of the physicochemical properties of the gonads of S. franciscanus, which in turn can be used as novel sources of nutritional or functional foods.

Key words: Strongylocentrotus franciscanus, gonads, morphology, proximal composition, sea urchin.

\section{INTRODUCTION}

Sea urchins are echinoid, from the class of marine invertebrates that belong to the Echinodermata phylum; distributed in every sea from Arctic to Antarctic regions (James, 2008). They inhabit rocky substrates at depths of the bathyal and abyssal zone (Tuya et al., 2004; Furman and Heck, 2009). The edible parts of the sea urchin are the gonads, which represent approximately $10 \%$ of the total body weight (De la Cruz-García et al., 2000). Sea urchin gonads are considered nutritious and healthy foods, due to their positive effects on health derived from its constituent's lipids, proteins, polysaccharides, carotenoids, vitamins and minerals (Archana and Babu, 2016). In Mexico, sea urchin (Strongylocentrotus franciscanus) gonads have great commercial importance, due to the generation of jobs and foreign exchange during fishing season mainly in the state of Baja California (PalleiroNayar et al., 2008). Its organoleptic characteristics make it a delight with great demand in the Asian market (Sloan, 1985; Yokota et al., 2002). These are appreciated for their orangeyellow color, bittersweet taste and distinctive aroma (Shpigel et al., 2005). Some gonads are a source of vitamins, minerals and other micronutrients, although the diet of the sea urchin can influence the biochemical composition of the gonads

*Autor para correspondencia: Joe Luis Arias-Moscoso Correo electrónico: jarias.moscoso@itvy.edu.mx

Recibido: 7 de enero de 2019

Aceptado: 8 de marzo de 2019 
(Chen et al., 2010). The physical and chemical characteristics of the sea urchin (Strongylocentrotus franciscanus) have been little studied; the most recent studies focus on sea urchins Strongylocentrotus droebachiensis, Stomopneustes variolaris and Strongylocentrotus nudus (Zhu et al., 2010; Pozharitskaya et al., 2015; Archana and Babu 2016; Zhou et al., 2018).

In the northwest region of Mexico, there are 18 sea urchin gonad processing plants operating; in 2017, 2788 tons of live weight of gonads were landed; it occupies the 16th place of the fishing species exported mainly to the United States (SAGARPA, 2017).

The objective of this study was to determine some chemical and physical characteristics of the sea urchin gonads (Strongylocentrotus franciscanus), using destructive and non-destructive methods. The analyzes included determining the proximal composition, molecular weight distribution by electrophoretic analysis, amino acid profile and scanning electron microscopy (SEM). The results could provide the theoretical basis for the use of sea urchin gonads as novel sources of functional foods and provide essential data for future scientific research.

\section{MATERIALS AND METHODS}

\section{Sample collection and preparation}

Sea urchins (Strongylocentrotus franciscanus) with a diameter greater than $120 \mathrm{~mm}$ were collected with the scubadivers from the coastal area of San Carlos, Nuevo Guaymas, during their maturation period, between the months of june and august. All organisms collected were transported to the laboratory in sea water to the aquaculture laboratory of Instituto Tecnológico del Valle del Yaqui, where shells were opened, gonads extracted, frozen in dry ice at $-40^{\circ} \mathrm{C}$ (freezing time was $15 \mathrm{~min}$ ) and stored at $-25 \pm 2{ }^{\circ} \mathrm{C}$ until further processing. For the molecular weight distribution, amino acid composition and morphology studies, samples consisted of freeze-dried sea urchin gonads.

\section{Proximate composition of gonads}

Moisture and ash content of sea urchin gonads were determined according to the standard procedures of the Association of the Official Analytical Chemists (AOAC, 1998) 980.46 and 938.08 respectively. Crude protein content was evaluated by Kjeldhal method 928.08 (AOAC, 1998) while total lipids were extracted and quantified by the method of Bligh and Dyer (1959), where conversion factors were 5.65 and 9.5 for protein and lipid respectively (Mol et al., 2008). Each analysis was done in triplicate.

\section{Molecular weight distribution of gonads protein}

For this analysis, we used freeze-dried gonad samples. The molecular weight protein distribution for the gonads was determined using a dissociating sodium dodecyl sulfate (SDS) buffer system in a discontinuous gel (4\% stacking gel and $10 \%$ separating gel) (Laemmli, 1970). Electrophoresis was performed using a Mini-Protean Tetra Cell (Bio-Rad Laboratories Chemical, Hercules, CA, USA) vertical electro- phoresis device. The running buffer was prepared with 16 $\%$ tris, $78 \%$ glycine and $6 \%$ SDS. Molecular weight standard (Sigma Chemical Company, St. Louis, MO, USA), and gonad sample were loaded as $15 \mu \mathrm{L}$ aliquots onto the gel, and electrophoresis was performed at 120 volts, room temperature for $60 \mathrm{~min}$. Protein bands were stained with $0.1 \%$ Coomassie brilliant blue R250 and distained with $10 \%$ acetic acid and $50 \%$ methanol solution. The molecular weight standard consisted of myosin (205 kDa), $\beta$-galactosidase (116 kDa), phosphorylase-b $(97.4 \mathrm{kDa})$, bovine serum albumin $(66 \mathrm{kDa})$, ovalbumin $(45 \mathrm{kDa})$, and carbonic anhydrase $(29 \mathrm{kDa})$. Gels were analyzed using a Bio-Rad Molecular Imager Universal Hood II - S.N. 76S/02460 Gel Doc XR System.

\section{Amino acid composition}

The amino acid content was determined through reversed-phase high-performance liquid chromatography (HPLC) using a Hewlett-Packard 1100 series HPLC system (Waldbronn, Germany) (Vázquez-Ortiz et al., 1995). Briefly, samples were hydrolyzed using $6 \mathrm{M} \mathrm{HCl}$ in evacuated, sealed tubes at $150{ }^{\circ} \mathrm{C}$ for $6 \mathrm{~h}$. The hydrolysates were diluted with $0.4 \mathrm{M}$ sodium borate buffer, derivatized with 4-chloro-7-nitro-1,2,3-benzoxadiazole, and heated to $60^{\circ} \mathrm{C}$ for $5 \mathrm{~min}$. Chromatograms were recorded, and the integrations calculated using ChemStation software (Agilent Technologies Inc., Palo Alto, CA, USA). The fluorescence emission was continuously monitored at 330 and $418 \mathrm{~nm}$.

\section{Morphology}

Micrographs of freeze-dried sea urchin gonads were generated to investigate the gonad morphological characteristics. After freeze drying and layering samples with 13 $\mathrm{mm}$ carbon paper tape and $20 \mathrm{~nm}$ gold coating, the freezedried sea urchin gonads morphology was measured using scanning electron microscope (SEM) model (JSM 5400LV scanning electron microscope, Peabody, MA, USA) at an acceleration voltage of $1.5 \mathrm{kV}$.

\section{RESULTS AND DISCUSSION}

\section{Proximal composition}

Table 1 shows the proximal composition for sea urchin S. franciscanus gonads. The moisture content of S. franciscanus gonads $(75.4 \% \pm 0.51)$ was similar to that observed in other sea urchin species (Dincer and Cakli, 2007; Archana and Babu, 2016). Ash content $(3.73 \% \pm 0.05)$ of the gonad was higher than those reported for S. nudus $(1.5 \% \pm 0.1)$ (Zhu et al., 2010), and similar to S. variolaris gonads $(3.76 \% \pm 0.25)$ indicating a high mineral content. In the present study, protein was the main constituent and lipid content was relatively abundant. Total protein content of $S$. franciscanus gonads $(13.63 \% \pm 0.57)$ was higher than S. variolaris $(12.10 \pm 0.41)$, S. nudus $(11.1 \% \pm 0.2)$ and P. lividus $(12.03 \% \pm 1.26)$ (Dincer and Cakli, 2007; Zhu et al., 2010; Archana and Babu, 2016). This variation in protein content relates with the season of capture (Mol et al., 2008); indicating an increase of protein content during the month of june for Paracentrotus lividus 
Tabla 1. Composición proximal de las gónadas de erizo de mar (Strongylocentrotus franciscanus).

Table 1. Proximate composition of sea urchin (Strongylocentrotus franciscanus) gonads.

\begin{tabular}{lcccc}
\hline $\begin{array}{l}\text { Composition } \\
\text { of gonads }\end{array}$ & $\begin{array}{c}\text { S. } \\
\text { franciscanus }\end{array}$ & $\begin{array}{c}\text { S. } \\
\text { variolaris * }\end{array}$ & $\begin{array}{c}\text { S. } \\
\text { lividus * }\end{array}$ & $\begin{array}{c}\text { S. } \\
\text { nudus ** }\end{array}$ \\
\hline Protein (\%) & $13.63 \pm 0.57$ & $12.10 \pm 0.41$ & $12.03 \pm 1.26$ & $11.1 \pm 0.2$ \\
\hline Lipid (\%) & $5.04 \pm 0.4$ & $4.98 \pm 0.30$ & $3.05 \pm 0.5$ & $7.1 \pm 0.2$ \\
\hline Ash (\%) & $3.73 \pm 0.05$ & $3.76 \pm 0.25$ & $2.25 \pm 0.24$ & $1.5 \pm 0.1$ \\
\hline Moisture (\%) & $75.40 \pm 0.51$ & $77.53 \pm 0.80$ & $79.65 \pm 0.65$ & $74.9 \pm 0.5$ \\
\hline
\end{tabular}

Determinations were performed in triplicate and data corresponded to mean values

* Values taken from the article (Archana \& Babu, 2016).

** Values taken from the article (Zhu et al., 2010).

gonads. It is also possible to relate differences in gonads protein content of the different species of sea urchins, with the type of diet, since the abundance of the algae that consume will directly affect the proximal composition (Liyana-Pathirana et al., 2002; Mol et al., 2008). This variation might explain in part differences in organoleptic properties of the various species (Chen et al., 2010).

Lipid content in gonads resulted with values $(5.04 \%$ $\pm 0.57)$ similar to that $S$. variolaris $(4.98 \% \pm 0.30)$ (Archana and Babu, 2016), but higher than other sea urchins, such as P. lividus (3.05\% \pm 0.5$)$ (Mol et al., 2008) and lower than $S$. nudus (7.1\% \pm 0.2 ) (Zhu et al., 2010). High lipid contents in sea urchin gonads may account for their nutritional and health functions (Zhou et al., 2018). The results indicated the state of health and maturity of the sea urchin gonads, which is related to the lipid content in gonads and membranes of the internal coating of the body wall, those have an important function of nutrient storage, protection and survival (Gonzalez-Duran et al., 2008; Shikov et al., 2017).

\section{Molecular weight distribution of gonads protein}

Some functional and biological properties of protein sources have been attributable to fractions of different molecular size (Rao et al., 2014). The protein molecular weights detected by SDS-PAGE patterns shown in (Fig. 1), molecular weight marker injected in lane $A$, and in lane $B$ sea urchin gonads.

The electrophoretic pattern showed strong bands around $140 \mathrm{kDa}$ and $58 \mathrm{kDa}$, although is important to mention the presence or several bands around 97 to $200 \mathrm{kDa}$. These bands have been previously associated to myofibrillar (myosin heavy chain, paramyosin, actinin) and connective (collagen) proteins in muscle of marine species (Rosas-Romero et al., 2010; Tan and Chang, 2018). Also, the electrophoretic profile showed 4 components of medium molecular weight around 55 to $97 \mathrm{kDa}$, this is related to a series of sarcoplasmatic proteins (enzymes mainly) (Ladrat, et al., 2003; LopezEnriquez, et al., 2015). It also shows 3 low molecular weight components at the $55 \mathrm{kDa}$, which could be related to actin. This pattern of components is similar to the report of sea urchin, Strongylocentrotus purpuratus related to the content

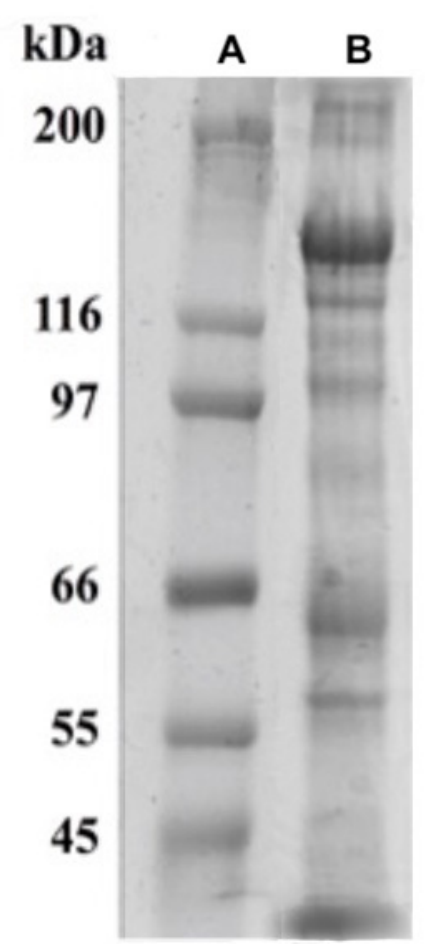

Figura 1. Análisis electroforético de las gónadas de erizo de mar (Strongylocentrotus franciscanus) liofilizadas. Líneas: A marcadores de peso molecular, $B$ gónadas de erizo de mar.

Figure 1. Electrophoretic analysis of freeze-dried sea urchin (Strongylocentrotus franciscanus) gonads. Lines: A molecular weight markers, B sea urchin gonads.

of macromolecules (Stewart et al., 2005). The function of the myofibrillar and sarcoplasmic proteins are directly related to muscle contraction, depending on the content of both, the contraction movement will be carried out in a fast or slow and sustained manner (Murray et al., 2007). The sea urchin gonads are covered by connective tissue, which covers the gonadal walls, these muscles contract rhythmically during the release of the gamete, in the reproduction period (Lawrence, 2006). For a more accurate identification of each band, further separation and purification processes are needed.

\section{Amino acid composition}

The amino acid composition of sea urchin (S. franciscanus) gonads was expressed as $\mathrm{g}$ per $100 \mathrm{~g}$ and is shown in Table 2. Amino acids, peptides and proteins are important components of food; as they provide the necessary elements for the synthesis of proteins, amino acids and peptides contribute directly to the flavor of food and are precursors of the aromatic components and colored substances that are formed by thermal and / or enzymatic reactions (Belitz et al., 2009).The major non-essential amino acids were aspartic acid, glycine and glutamic acid; with contents significantly higher $(p<0.05)$ than the other amino acids in this study. The main essential amino acids were threonine and leucine. Similar behavior was reported for the sea urchin (P. lividus), which indicates higher leucine content (Mol et al., 2008).The composition of amino acids is of importance because they allow the formation of proteins in the other hand they play 
Tabla 2. Composición de aminoácidos de las gónadas de erizo de mar (Strongylocentrotus franciscanus) ( $\mathrm{g} / 100 \mathrm{~g}$ base seca).

Table 2. Amino acid composition of sea urchin (Strongylocentrotus franciscanus) gonads ( $\mathrm{g} / 100 \mathrm{~g}$ dry base).

\begin{tabular}{|c|c|}
\hline Amino acids & Mean \pm SD \\
\hline \multicolumn{2}{|c|}{ Non-essential amino acids } \\
\hline Aspartic acid & $11.58 \pm 0.05$ \\
\hline Glutamic acid & $9.55 \pm 0.01$ \\
\hline Glycine & $10.60 \pm 0.02$ \\
\hline Alanine & $8.52 \pm 0.09$ \\
\hline Tyrosine & $2.35 \pm 0.12$ \\
\hline Proline & $8.46 \pm 0.10$ \\
\hline Taurine & $8.43 \pm 0.45$ \\
\hline Total & 59.49 \\
\hline \multicolumn{2}{|c|}{ Essential amino acids } \\
\hline Lysine & $3.54 \pm 0.71$ \\
\hline Histidine & $5.85 \pm 0.82$ \\
\hline Threonine & $6.35 \pm 0.58$ \\
\hline Methionine & $2.24 \pm 0.02$ \\
\hline Valine & $5.68 \pm 0.49$ \\
\hline Leucine & $6.73 \pm 0.94$ \\
\hline Isoleucine & $5.49 \pm 0.17$ \\
\hline Phenylalanine & $4.46 \pm 0.26$ \\
\hline Total & 40.34 \\
\hline
\end{tabular}

Data are show as mean \pm standard deviation $(\mathrm{SD})$, obtained from triplicate determinations.

an important role in giving the sensory and nutritional characteristics to various foods (Murata and Sata, 2000; Osako et al., 2006a; Belitz et al., 2009). Glycine, threonine, proline and alanine are considered amino acids responsible for sweet taste, while isoleucine, valine, and leucine contribute to the bitter taste; glutamic acid is responsible for the umami flavor (Komata, 1964; Osako et al., 2006a). The amino acid levels responsible for the bitter taste are mainly due to the content of these amino acids in the algae that they consume; S. franciscanus consumes mainly brown algae of the type Macrocystis integrifolia, and Macrocystis pyrífera (Osako et al., 2006b; Palleiro-Nayar et al., 2008; Capinpin, 2015).

\section{Morphology of S. franciscanus gonads}

Particle size analysis is important to determine their physical associations (Goldan et al., 1997) and biotechnological applications. Morphological characterization of S. franciscanus gonads was carried out through scanning electronic microscopy (Fig. 2). The gonads morphology was analyzed at different magnifications to detect structures present. In Fig. $2 \mathrm{~A}$ a homogeneous structure is observed, somewhat rough
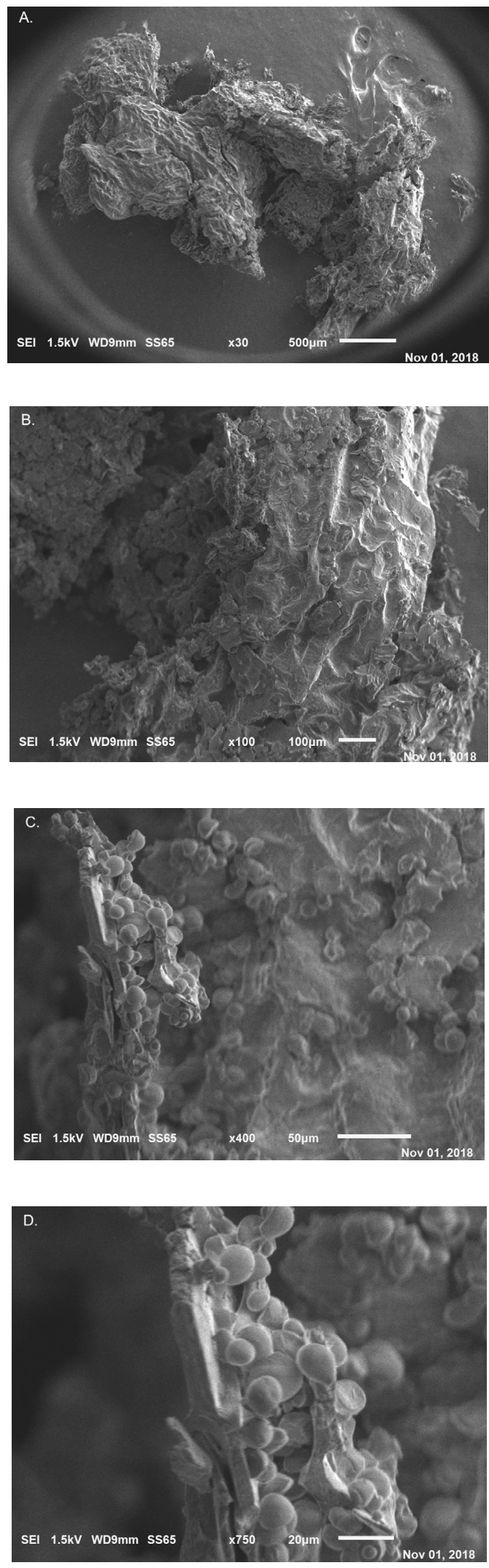

Figura 2. Micrografías del microscopio electrónico de barrido de gónadas de S. franciscanus: A: 30x; B: 100X; C: 400X; D: 750x.

Figure 2. Scanning electron microscope micrographs of $S$. franciscanus gonads: A: 30x; B: 100X; C: 400X; D: 750x. 
and uniform, as the image is magnified (Fig. 2B) is possible to detect sections with granular formations. It is important to mention that each protein offers a characteristic conformation, the three-dimensional organization will be determined by the type of protein (Damodaran et al., 2010; Alberts et al., 2014). Thus, the fibrous proteins are constituted by polypeptide chains arranged along a common straight axis which leads to the formation of fibers. In none of the micrographs is possible to detect this type of structures, however, the globular proteins consist of several polypeptide chains folded on themselves to form spherical or globular three-dimensional structures (Damodaran et al., 2010; Alberts et al., 2014). As it can be seen in Fig. $2 \mathrm{C}$ and 2D, it is possible to detect this type of structures, which is repeated in several sections of the sample analyzed. Possibly related to the presence of actin as mentioned in the study conducted by Cline et al. (1983), where structures similar to those reported during the fertilization of the sea urchin (Arbacia punctulata and Lytechinus variegatus) are observed. Results of micrographs may confirm the presence of fibrillar and globular proteins detected in the electrophoretic profile (Kang et al., 2017).

\section{CONCLUSIONS}

The present study reports for the first time the morphological characteristics of the sea urchin S. franciscanus gonads with SEM. Likewise, from the chemical characteristics of its proximal composition, the data obtained confirmed that the gonads have a protein and lipid content with feasibility to be used in the food industry. The amino acids detected are responsible for the characteristic flavors of this food. It has been concluded that the $S$. franciscanus gonads from the coasts of Sonora-Mexico contain chemical and nutritious components with potential to be analyzed in greater detail.

\section{REFERENCES}

Alberts, B., Johnson, A., Lewis, J., Raff, M., Roberts, K., and Walter, P. 2014. Molecular Biology of the Cell W. W. N. Company Ed. 6 ed.

AOAC. 1998. Official methods of analysis of AOAC international. 16th ed. Gaithersbury, Maryland, USA.

Archana, A., and Babu, K. R. 2016. Nutrient composition and antioxidant activity of gonads of sea urchin Stomopneustes variolaris. Food Chemistry. 197: 597-602.

Belitz, H. D., Grosch, W., and Schieberle, P. 2009. Amino Acids, Peptides, Proteins. 4 ed. Food Chemistry: Springer-Verlag Berlin Heidelberg.

Bligh, E. G., and Dyer, W. J. 1959. A rapid method for total lipid extraction and purification. Canadian Journal of Biochemistry and Physiology. 37: 911-917.

Capinpin, E. C. 2015. Growth and survival of sea urchin (Tripneustes gratilla) fed different brown algae in aquaria International Journal of Fauna and Biological Studies. 2:3, 56-60.

Chen, G. Q., Xiang, W. Z., Lau, C. C., Peng, J., Qiu, J. W., Chen, F., Jiang, Y. 2010. A comparative analysis of lipid and carotenoid composition of the gonads of Anthocidaris crassispina,
Diadema setosum and Salmacis sphaeroides. Food Chemistry. 120: 4, 973-977.

Cline, C. A., Schatten, H., Balczon, R., and Schatten, G. 1983. Actinmediated surface motility during sea urchin fertilization. Cell Motility. 3: 5, 513-524.

Damodaran, S., Parkin, K. L., and Fennema, O. R. 2010. FENNEMA Química de los alimentos 3th ed. Editorial Acribia S. A.

De la Cruz-García, C., López-Hernández, J., González-Castro, M. J., Rodrínguez-Bernaldo De Quirós, A. L., and Simal-Lozano, J. 2000. Protein, amino acid and fatty acid contents in raw and canned sea urchin (Paracentrotus lividus) harvested in Galicia (NW Spain). Journal of the science of food and agriculture. 80: 1189-1192.

Dincer, T., and Cakli, S. 2007. Chemical composition and biometrical measurements of the Turkish sea urchin (Paracentrotus Lividus, Lamarck, 1816). Critical Reviews in Food Science and Nutrition. 47: 1, 21-26.

Furman, B., and Heck, K. I. 2009. Differential impacts of echinoid grazers on coral recruitment. Bulletin of Marine Science. 85: 2,121-132.

Goldan, O., Popper, D., and Karplus, I. 1997. Management of size variation in juvenile gilthead sea bream (Sparus aurata). I: Particle size and frequency of feeding dry and live food. Aquaculture. 152: 1-4, 181-190.

Gonzalez-Duran, E., Castell, J. D., Robinson, S. M. C., and Blair, T. J. 2008. Effects of dietary lipids on the fatty acid composition and lipid metabolism of the green sea urchin Strongylocentrotus droebachiensis. Aquaculture. 276: 1-4, 120-129.

James, D. B. 2008. Indian echinoderms their resources biodiversity zoogeography and conservation. Glimpses of Aquatic Biodiversity. 7: 120-132.

Kang, H., Bang, I., Jin, K. S., Lee, B., Lee, J., Shao, X., Heier, J. A., Kwiatkowski, A. V., Nelson, W. J., Hardin, J., Weis, W. I., Choi, H.-J. 2017. Structural and functional characterization of Caenorhabditis elegans a-catenin reveals constitutive binding to $\beta$-catenin and F-actin. Journal of Biological Chemistry. 292: 17, 7077-7086.

Komata, Y. 1964. Study on the extractives of "uni" IV. Taste of each component in the extractives. Nippon Suisan Gakkaishi. 30: 749-756.

Ladrat, C., Verrez-Bagnis, V., Noël, J., and Fleurence, J. 2003. In vitro proteolysis of myofibrillar and sarcoplasmic proteins of white muscle of sea bass (Dicentrarchus labrax L.): effects of cathepsins B, D and L. Food Chemistry. 81: 4, 517-525.

Laemmli, U. 1970. Cleavage of structural proteins during assembly of the head bacteriophage T4. Nature Genetics. 227: 5259, 680-685.

Lawrence, J. M. 2006. Gametogenesis and Reproduction of Sea Urchins. En: Edible Sea Urchins: Biology and Ecology. 2 ed., pp 11-33. Elsevier. Tampa, Florida.

Liyana-Pathirana, C., Shahidi, F., and Whittick, A. 2002. The effect of an artificial diet on the biochemical composition of the gonads of the sea urchin (Strongylocentrotus droebachiensis). Food Chemistry. 79: 4, 461-472.

Lopez-Enriquez, R. L., Ocano-Higuera, V. M., Torres-Arreola, W., Ezquerra-Brauer, J. M., and Marquez-Rios, E. 2015. Chemical and functional characterization of sarcoplasmic proteins from giant squid (Dosidicus gigas) mantle. Journal of Chemistry. 2015: 1-10. 
Mol, S., Baygar, T., Varlik, C., and Tosun, S. Y. 2008. Seasonal variations in yield, fatty acids, amino acids and proximate composition of sea urchin Paracentrotus lividus roe. Journal of Food and Drug Analysis. 16: 2, 68-74.

Murata, Y., and Sata, N. U. 2000. Isolation and Structure of Pulcherrimine, a Novel Bitter-Tasting Amino Acid, from the Sea Urchin (Hemicentrotus pulcherrimus) Ovaries. Journal of Agricultural and Food Chemistry. 48: 11, 5557-5560.

Murray, R. K., Granner, D. K., Rodwell, V. W. 2007. Harper Bioquímica ilustrada. 17a ed. México.

Osako, K., Kiriyama, T., Ruttanapornvareesakul, Y., Kuwahara, K., Okamoto, A., and Nagano, N. 2006a. Free amino acid composition of the gonad of the wild and cultured sea urchins Anthocidaris crassispina. Aquaculture Science. 54: 3, 301-304.

Osako, K., Hossain, M. A., Ruttanapornvareesakul, Y., Fujii, A., Kuwahara, K., Okamoto, A., Nagano, N. 2006b. The aptitude of the green alga Ulva pertusa as a diet for purple sea urchin Anthocidaris crassispina. Aquaculture Science. 54: 1, 15-23.

Palleiro-Nayar, J. S., Salgado-Rogel, M. L., and Montero-Aguilar, D. 2008. La pesca del erizo morado, Strongylocentrotus purpuratus, y su incremento poblacional en Baja California, México. Ciencia Pesquera. 16: 29-35.

Pozharitskaya, O. N., Shikov, A. N., Laakso, I., Seppänen-Laakso, T., Makarenko, I. E., Faustova, N. M., Makarova, M. N., Makarov E. G. 2015. Bioactivity and chemical characterization of gonads of green sea urchin Strongylocentrotus droebachiensis from Barents Sea. Journal of Functional Foods. 17: 227-234.

Rao, M. A., Syed, S. H., Rizvi, A., and Ahmed, J. 2014. Engineering properties of foods. Forth ed. Boca Raton CRC Press.

Rosas-Romero, Z. G., Ramirez-Suarez, J. C., Pacheco-Aguilar, R., Lugo-Sánchez, M. E., Carvallo-Ruiz, G., and García-Sánchez, G. 2010. Partial characterization of an effluent produced by cooking of Jumbo squid (Dosidicus gigas) mantle muscle. Bioresource technology. 101: 2, 600-605.

SAGARPA. 2017. Anuario estadístico de acuacultura y pesca. Comision Nacional de Acuacultura y Pesca. México.
Shikov, A. N., Laakso, I., Pozharitskaya, O. N., Seppänen-Laakso, T., Krishtopina, A. S., Makarova, M. N., Vuorela, H., Makarov, V. 2017. Chemical Profiling and Bioactivity of Body Wall Lipids from Strongylocentrotus droebachiensis. Marine Drugs. 15: 12, 365.

Shpigel, M., Mc Bride, S. C., Marciano, S., Ron, S., and Ben-Amotz, A. 2005. Improving gonad colour and somatic index in the European sea urchin Paracentrotus lividus. Aquaculture. 245: 1-4, 101-109.

Sloan, N. A. 1985. Echinoderm fisheries of the world: A review. Echinodermata Rotterdam, Netherlands: A. A. Balkem Publishers.

Stewart, P. L., Makabi, M., Lang, J., Dickey-Sims, C., Robertson, A. J., Coffman, J. A., Suprenant, K.A. 2005. Sea urchin vault structure, composition, and differential localization during development. BMC Developmental Biology. 5: 3, 1-12.

Tan, Y., and Chang, S. K. 2018. Isolation and characterization of collagen extracted from channel catfish (Ictalurus punctatus) skin. Food Chemistry. 242: 147-155.

Tuya, F., Boyra, A., Sanchez-Jerez, P., Barbera, C., and Haroun, R. 2004. Can one species determine the structure of the benthic community on a temperate rocky reef? The case of the longspined sea-urchin Diadema antillarum (Echinodermata: Echinoidea) in the eastern Atlantic. Hydrobiologia. 519: 1-3, 211-214.

Vázquez-Ortiz, F. A., Caire, G., Higuera-Ciapara, I., and Hernández, G. 1995. High performance liquid chromatographic determination of free amino acids in shrimp. Journal of Liquid Chromatography. 18: 10, 2059-2068.

Yokota, Y., Matranga, V., and Smolenicka, Z. 2002. The sea urchin: From basic biology to aquaculture. Rotterdam A. A. Balkem Publishers.

Zhou, X., Y., Z. D., Lu, T., Liu, Z. Y., Zhao, Q., Liu, Y. X., Hu, X. P., Zhang, J. H., and Shahidi, F. 2018. Characterization of lipids in three species of sea urchin. Food Chemistry. 241: 97-103.

Zhu, B. W., Qin, L., Zhou, D. Y., Wu, H. T., Wu, J., Yang, J. F., Li, D. M., Dong, X. P., and Murata, Y. 2010. Extraction of lipid from sea urchin (Strongylocentrotus nudus) gonad by enzymeassisted aqueous and supercritical carbon dioxide methods. European Food Research and Technology. 230: 5, 737-743. 